\title{
os mineiros em santa catarina: emprego, salários, relação capital $x$ trabalho e produtividade da mão-de-obra (1980-1999)
}

\author{
Maurício Aurélio dos Santos \\ Doutor em História Econômica pela USP, professor da UDESC e da UNISUL, membro do \\ Instituto Histórico e Geográfico de Santa Catarina - IHGSC e líder do grupo de pesquisa \\ "Instituição, Políticas Públicas e Trabalho"
}

\section{RESUMO}

Dentre os reflexos da crise econômica do final da década de 1980 e início da década de 1990 , bem como da adoção do receituário neoliberal que deu sinais já no governo Sarney (1985-1989), mas que passou a dirigir a política econômica nos governos de Collor e Fernando Henrique Cardoso,houve conseqüências marcantes ao mercado de trabalho no Sul de Santa Catarina. No setor carbonífero, que vivia desde Vargas sob a proteção estatal, o mercado de trabalho foi o primeiro a sofrer as conseqüências com as primeiras variações negativas no estoque de vagas, já em meados da década de 1980. Entretanto sua maior crise vai ocorrer justamente na década de 1990 , com a desregulamentação da atividade e com as privatizações, que envolveram tanto diretamente o setor, como na Carbonífera Próspera, como indiretamente, com no Lavador de Capivari, na Indústria Carboquímica Catarinense e na Usina Termelétrica Jorge Lacerda. Além da redução drástica das vagas no mercado de trabalho, com mudança significativa na posição do setor carbonífero na oferta de vagas ao mercado de trabalho do Sul de Santa Catarina, ocorreu a precarização das condições de trabalho, com redução das rendas do trabalho e com o enfraquecimento dos sindicatos e das lutas dos trabalhadores $\mathrm{mi}$ neiros.

Palavras-chave: neoliberalismo, privatização, indústria carbonífera, emprego, salários, relações de trabalho.

\section{ABSTRACT}

Among the economical crisis results on the end of 1980's and the beginning of 1990's, as well as the neo-liberal income adoption that has already given signals to Sarney's government, but that started leading the economical policy in Collors and Fernando Henrique Cardosos governments, there were remarkable consequences on the work market in the South of Santa Catarina. In the coal-fired power sector, that had lived since Vargas under the state protection, the work market was the first to suffer the consequences with the first negative variations on the vacant stock, on the middle 80's. Although, its greatest crisis happened justly on the 1990 's, with the deregulation activity and with the privatization, that involved directly the sector, as in Prospera Coal-fired Industry, as indirectly, with Lavador de Capivari, Catarinense Coal-chemistry Industry and Jorge Lacerda Coal Power Station. B esides, the sharp reduction on the work market vacant with significant changes on the coal-fired sector position related to vacant offerings on the work market in the South of Santa Catarina, happened the precarious work conditions with work income reductions and with the Unions weaken and miner-workers' fight.

Key words: neo-liberalism, privatization, coal-fired power industry, job, wages, work reductions. 
Este trabalho tem por objetivo ajudar a entender quais as conseqüências da adoção do neoliberalismo, com sua desregulamentação e suas privatizações, para o mercado de trabalho do setor carbonífero de Santa Catarina', nos aspectos ligados a oferta de vagas no mercado de trabalho, aos salários, passando pela sindicalização e pela produtividade da mão-de-obra. Ele foi elaborado a partir dos dados e das reflexões que estão presente em minha tese de doutoramento em história econômica, na Universidade de São Paulo, USP (Brasil), realizada de 1988 a 2001, intitulada "Acumulação, geração de emprego e diversificação da economia no Sul de Santa Catarina (Brasil): carvão, cerâmica e a indústria de plásticos".

O processo de consolidação do setor carbonífero em nossa região de estudo se deu no início do século XX sob a proteção do Estado e estava ligado a substituição de importações imposta pelas crises mundiais. O setor vivia seus momentos de crescimento quando a economia mundial passava por crises. Foi assim com a Primeira Guerra Mundial, com a Crise de 1929, com a Segunda Guerra Mundial, Crises do Petróleo etc. ${ }^{2}$ e o Estado brasileiro criou diversos mecanismos para proteger a atividade que representava uma fonte de energia cara, mas essencial para substituir os energéticos importados nos momentos em que seu preço estava alto ou com acesso dificultado. Assim, estudar quais as conseqüências da adoção do neoliberalismo, que impôs a desregulamentação da atividade e a privatização da Carbonífera Próspera e de toda uma estrutura, como o lavador de Capivari, obrigando o setor a se adaptar a uma realidade para a qual ele não estava preparado, com graves conseqüências ao mercado de trabalho.

Nossa região de estudo foi colonizada, principalmente, por imigrantes italianos, que tinham a base da atuação econômica concentrada, inicialmente, na agricultura. Antes dos italianos, entretanto, já eram registrados em Laguna os vicentistas, vindos de Santos-SP e originários de São Vicente de Fora - Portugal; e alemães, que proce-

A Indústria Carbonífera de Santa Catarina localiza-se no Sul do Estado, único lugar do Estado com a presença deste mineral. Santa Catarina é o penúltimo estado do Sul do Brasil, que faz fronteira com a Argentina e fica próximo aos demais países membros do Mercosul e vem, desde 1960, apresentando índices de crescimento industrial superiores a média brasileira.

Sobre as crises da atividade de mineração do carvão no Sul de Santa Catarina ver SANTOS, 1997. 
deram de São Pedro de Alcântara ${ }^{3}$, via Braço do Norte, Armazém, São Ludgero, dentre outras.

Dos municípios produtores de carvão, Urussanga foi o primeiro a ser povoado (1878), em terras do município de Tubarão, desmembrando-se em 1900. De Urussanga, surgiram três vilas, que mais tarde se transformaram em municípios: Nova Belluno, hoje Siderópolis, colonizada em 1891 e emancipada em 1958; Morro da Fumaça, ocupada em 1910 e emancipada em 1962; e Cocai do Sul, fundada em 1895 e emancipada em 1991.

Em 06 de janeiro de 1880, dois anos após Urussanga, é fundada e efetivamente ocupada São José de Cresciúma, hoje Criciúma, que teve sua colonização inicial igualmente feita por italianos. Recebe, pouco depois, a contribuição de poloneses (1891) e, mais tarde (1912), de alemães. De Criciúma surgiram três vilas, que depois de passarem a distritos tornaram-se municípios: Nova Veneza, emancipada em 1958, Içara em 1961 e Forquilhinha em 1989.

Lauro Muller foi o único município produtor de carvão que teve sua origem ligada à extração do carvão. Assim, com exceção de Lauro Müller, a região tinha como primeira atividade econômica à agricultura, como vimos, e como atividade complementar à pecuária de subsistência.

Antes de sua fundação a região era trilhada por tropeiros que desciam a Serra do Doze (Serra do Rio do Rastro) rumo a Laguna, no litoral, e que descobriram o carvão. A partir daí, a área carbonífera do Sul do Estado passou a ser objeto de estudos geológicos, dos quais resultariam, efetivamente, as perspectivas futuras de desenvolvimento econômico da região e a base de sua estrutura urbana.

Nossa região de estudo conseguiu amenizar os efeitos das grandes crises mundiais por possuir energético alternativo às fontes tradicionais de energia, e com isso viveu momentos de prosperidade e de baixo índice de desemprego, se comparado com outras regiões

São Pedro de Alcântara foi o primeiro núcleo de colonização alemã em Santa Catarina, estabelecido em 1828 e que por diversos motivos não prosperou.

A vila foi fundada em 1885, ano em que teve início a exploração, com o nome de Estação das Minas. Em 1921 foi elevada à categoria de distrito e, em 1956, é emancipada de Orleans. "Seu nome é unia homenagem ao ex-governador Lauro Müller que, quando Ministro da Viação e Obras Públicas, do Governo Federal, muito fez em prol das atividades de mineração do carvão na região". (PBDEE, v. I, p.36. AMREC/UNESC, 1997) 
do país, fruto do aumento do consumo do carvão, como aconteceu quando da I Guerra Mundial, da Crise de 1929, da II Guerra Mundial e das Crises do Petróleo da década de 1970, assim como quando da grande crise nacional do começo da década de 1980. A partir dali as coisas mudaram.

Se até então o modelo adotado pelo Brasil era o de Estado forte, interventor na economia, com os ventos neoliberais que começaram a soprar por terras verde e amarelas, e com a diversificação da economia regional, esse quadro mudou radicalmente. Primeiro pelo desmonte que sofreu a atividade de mineração do carvão, frente à política neoliberal, segundo pelo crescimento de outros setores, redundando num quadro completamente suscetível às variações na economia extra-regional e ao seu ritmo no crescimento econômico, cada vez menos protegido pelo Estado, que no afã de se tornar enxuto, magro, para agradar os organismos internacionais, caminha para a sua anorexia, para parafrasear B OXBERGER \& KLIMENTA ${ }^{5}$.

O modelo apregoado pela economia política neoliberal, com sua flexibilização, desregulamentação e privatização, tem espalhado enorme desemprego, só visto em algumas partes do mundo em épocas de grandes conflitos, como as Guerras Mundiais. A desproletarização do trabalho fabril, industrial, fruto do avanço tecnológico que diminuiu o volume de trabalho vivo em detrimento do trabalho morto, incorporado nas máquinas, nos instrumentos de trabalho e na tecnologia, aliada à economia política dominante e seus efeitos para o mercado de trabalho, já foi muito bem explorada por AN TUNES, BOXBERGER \& KLIMENTA, TEIXEIRA \& OLIVEIRA, SINGER, para citar apenas alguns.

No Brasil, podemos citar inúmeros exemplos de setores que estão sofrendo com a reestruturação produtiva imposta pela política neoliberal, que vem reduzindo, e em muito, as oportunidades de trabalho de diversas categorias, entre eles a dos bancários e a dos metalúrgicos, as que sofreram maiores perdas ${ }^{6}$.

Todos esses arranjos, aliados a uma série de outros fatores, têm levado o setor secundário a ocupar a posição que detinha em 1940, quando absorvia apenas $11 \%$ da mão-de-obra empregada no Brasil.

B OXBERGER \& KLIMENTA, 1999:106-116.

Ler GENTILI, 1995; OURIQUES \& RAMPINELLI, 1997; TEIXEIRA \& OLIVEIRA, 1998; A N T UNES, 1998; S INGER, 1999; A N T UNES, 2000; FERREIRA，\& ALVIM, 2001; CARNEIRO, 2002; ANTUNES, 2003. 
A diferença é que naquela época o maior absorvedor de mão-deobra era o setor primário, e hoje é o terceiro que mais emprega no Brasil. O problema é que, apesar do setor terciário vir aumentando absoluta e proporcionalmente o número de empregados, esse aumento não tem sido suficiente para atender à demanda de trabalhadores liberados pelas indústrias, quanto mais para atender àqueles que têm chegado ao mercado de trabalho, sem falar na alta potencialidade que o setor terciário tem de promover avanços tecnológicos e liberar mão-de-obra. Em Santa Catarina o emprego industrial vem caindo desde a década de 1980, embora tenha-se agravado na década de $1990^{7}$, quando só na indústria de transformação, segundo pesquisa da Federação da Indústria do Estado de Santa Catarina FIESC ${ }^{8}$ e do Departamento Intersindical de Estatística e Estudos Sócio-Econômicos - DIEESE-SC ${ }^{9}$, reduziu-se o número de vagas em quase $50 \%$.

"Estudo divulgado recentemente pela administração estadual, elaborado a partir dos registros do Ministério do Trabalho (Cadastro Geral de Empregados e Desempregados e Relação Anual de Informações Sociais), indica redução de quase 103 mil vagas em Santa Catarina no período 1990-1998, a esmagadora maioria na indústria de transformação."10

"(...) houve aprofundamento do processo de ajuste, orientado para a redução do tamanho das empresas e de suas estruturas organizacionais. (...) houve a combinação perversa da recessão com uma abertura da economia, precipitada e atabalhoada, que redundou em desemprego de grandes contigentes de pessoal e quebra inédita da produção industrial. (...) Portanto, fica o alerta: se o Estado vê aumentada sua população em 70 mil habitantes/ano e

S ANT OS, 1997:124, aponta um crescimento de $220 \%$, no acesso ao seguro desemprego em nossa região de estudo, de 1988/89, repetindo outro crescimento de $204 \%$ de $1989 / 90$ e outro grande crescimento de $1990 / 91$, na ordem de $128 \%$."É importante ressaltar que, de 1988 a 1991 , houve um aumento na procura pelo benefício na ordem de $522,7 \% "$, diz ele.

Pesquisa que mede a oferta de vagas na indústria catarinense em quase 380 indústrias.

DIEESE-SC, 1999:73.

LINS.Apud. SANTOS, 1.999: 205. 
se, ao invés de gerar empregos formais, os destrói, estará promovendo duas sociedades, com alargamento do fosso social entre elas - uma de desempregados e outra, com o emprego formal, mas, permanentemente em risco."11

Assim, podemos reafirmar que o desemprego não é somente um problema estrutural, como afirmam alguns, tendo a ver também com a conjuntura maior, isto é, com a política nacional. Para melhor compreender nossa problemática vamos ver em que medida as questões estruturais, do avanço tecnológico e as conjunturais, orquestradas pela adoção do neoliberalismo como política econômica, influenciaram no mercado de trabalho do Sul de Santa Catarina, a partir do setor carbonífero, quanto à oferta de empregos, à concentração da mão-de-obra por indústrias, às relações entre o capital e o trabalho, à evolução dos salários e o faturamento das indústrias por empregado, à formação e à qualificação profissional.

\section{A oferta de vagas}

Analisando os dados da oferta de mão-de-obra do setor carbonífero (Tabela 01) podemos observar que a mesma veio crescendo desde 1970, quando oferecia 6.000 vagas $^{12}$, até 1984 , com 10.898 empregos diretos. Neste período, a única exceção foi o ano de 1981 , quando o setor sofreu uma redução de $14,2 \%$ em relação ao ano anterior, uma espécie de aviso do que estava por vir. O primeiro sinal já havia sido dado em 1981, e em 1985, 1986 e 1987 a oferta de vagas caiu $3,3 \%, 7 \%$ e $6,4 \%$, sempre em relação ao ano anterior, respectivamente, representando uma queda de $15,6 \%$ no total de vagas no setor no período de 1980 a 1987. Os anos de 1988 e 1989 foram exceção ao movimento de queda iniciado em 1985: as vagas subiram de $9.264^{13}$ (1987) para 12.785 em 1988 e depois para 13.735 em 1989. Aliás, este foi o pico na evolução da oferta de empregos no setor, e

\footnotetext{
C UN H A, 1997:63 e 87.
}

Sendo 23.440 dependentes da atividade.

13 Segundo p. 201 do Informativo Anual da Indústria Carbonífera, D N P M, 1988, ano base 1987, havia em 19879.129 empregados nas carboníferas, entretanto os números que compuseram esta soma, não fecham com os apresentados no mesmo documento, quando apresentados por empresa, das páginas 15 a 134. Por orientação do próprio DNPM, estamos considerando os valores informados por empresa. 
esse aumento não tem nenhuma razão aparente, uma vez que de 1987 para 1988, embora a produção tenha aumentado $22 \%$, o emprego aumentou 39\%. Já de 1988 para 1989 a produção encolheu $15 \%$ e o emprego continuou crescendo, atingindo um índice de $7 \%$, representando um aumento, para o biênio em questão, de 3,7\% na produção e de $49,8 \%$ para o emprego, fazendo com que a produtividade da mão-de-obra atingisse o índice mais baixo de que se tenha notícia no setor carbonífero.

Tabela 01 . Números de empregados das indústrias carboníferas de Santa Catarina

\begin{tabular}{|c|c|c|c|c|c|c|c|c|c|c|c|c|c|c|}
\hline Empresas & 1981 & 1982 & 1985 & 1987 & 1990 & 1991 & 1992 & 1993 & 1994 & 1995 & 1996 & 1997 & 1998 & 1999 \\
\hline Próspera & 2.021 & 2274 & 2.139 & 2462 & & & 300 & 405 & 422 & 491 & & & & \\
\hline Metropolitana & 609 & 651 & 1.151 & 638 & 788 & 851 & 436 & 487 & 438 & 477 & 541 & 624 & 626 & 590 \\
\hline Criciúma & 1220 & 1.520 & 1.534 & 1.730 & 920 & 816 & 678 & 633 & 686 & 723 & 536 & 605 & 499 & 523 \\
\hline $\mathrm{CCU}$ & 2296 & 2303 & 2.037 & 1.869 & 1553 & 1241 & 695 & 811 & 612 & 508 & 346 & & zero & \\
\hline Treviso & 310 & 313 & 308 & 297 & 78 & 78 & 98 & 151 & 66 & 192 & 154 & 157 & zero & zero \\
\hline C B CA & 778 & 1.155 & 1.522 & 704 & 547 & 599 & 511 & 780 & 707 & 434 & 376 & 405 & 414 & 381 \\
\hline Barro Branco & 666 & 664 & 659 & 557 & 362 & 378 & 317 & 339 & 167 & 95 & 18 & 03 & 04 & 53 \\
\hline IBRAMIL & 77 & 117 & 335 & 281 & 97 & 165 & 120 & 54 & 33 & 32 & 18 & 12 & & \\
\hline Catarinense & 420 & 443 & 408 & 366 & 252 & 243 & 257 & 256 & 246 & 288 & 254 & 280 & 237 & 222 \\
\hline Palermo & 279 & 231 & se & 64 & & & & & & & & & & \\
\hline COCALIT & 339 & 476 & 188 & 141 & 35 & 41 & 41 & 103 & 93 & & 87 & 102 & & 85 \\
\hline $\begin{array}{l}\text { Rio Deserto } \\
\text { Barão R. Branco }\end{array}$ & D 307 & & 157 & 155 & & & & 82 & 40 & 03 & & & 561 & 665 \\
\hline Belluno & & & & & & & & & 105 & 164 & - & 145 & 189 & 284 \\
\hline Santa Luzia & & & & & & & & & & & & & 155 & \\
\hline Comin & & & & & & & & & & & & & 61 & 77 \\
\hline Cooperminas & & & & & & & & & & & & & 414 & 386 \\
\hline Minageo & & & & & & & & & & & & & 30 & 28 \\
\hline Pérola & & & & & & & & 87 & & & & & & \\
\hline São Domingos & & & & & & & & & & & & & & 45 \\
\hline TOTAL & 9.322 & 10.147 & 10.536 & 9.264 & 4.632 & 4.412 & 3.453 & 4.293 & 3.615 & 3.404 & 2.330 & 2.333 & 2.776 & 2.953 \\
\hline
\end{tabular}

Fontes:

1. Para 1981,1982,1985,1987,1993,1994,1995,1998 e 1999 - Informativo Anual da Indústria Carbonífera, DNPM

2. Demais anos SIECESC.

Podemos especular que tal comportamento (redução da produtividade da mão-de-obra pela diminuição da produção sem a diminuição do emprego) tenha se dado em função de os empresários do carvão não acreditarem que a crise perdurasse por muito tempo, não sendo tão profunda como foi, até porque não tinham vivido crise desta amplitude. Outra possibilidade, que não exclui a anterior, é de estarem iludidos com as promessas do candidato à presidência da República, Fernando Collor de Mello, crentes que o comprometi- 
mento dos políticos conservadores com a burguesia nacional e com o enriquecimento privado não tivesse sido abalado pelos ventos neoliberais, primeiro por não entender muito bem o que é e quais os efeitos desse viés ideológico e econômico ${ }^{14}$, segundo em função da polarização produzida pela mídia, durante o processo eleitoral, no qual Collor representava a família e a propriedade privada, e o Lula $^{15}$ o comunismo, o velho, e o fim da propriedade privada dos meios de produção. O que os empresários não conseguiram entender, ou não queriam, é que no discurso de modernidade de Collor havia entrelinhas nas quais o desmonte do Estado e o sucateamento da indústria nacional estavam embutidos. Uma outra possibilidade pode ser a auto-confiança das lideranças dos mineradores, que até então, conseguiram extrair vantagens em sua relação com o poder público.

É importante registrar aqui que as medidas neoliberais para a atividade carbonífera já vinham sendo adotadas no Governo Sarney, com o fim dos subsídios, por exemplo, muito embora seu efeito nem sempre tenha sido imediato. Além disso, muitos estudiosos creditam ao Collor a adoção do receituário neoliberal na atividade, com a desregulamentação da atividade, que foi a atitude mais drástica, mas não a primeira, constituindo-se na verdade em uma continuação da política adotada pelo Sarney para o setor.

A crise no mercado de trabalho desencadeada a partir de 1990 gerou na região dois tipos de êxodo. Um para outras cidades do Sul de Santa Catarina que não possuíam atividades de mineração, como Araranguá, Meleiro, Turvo e Imaruí, e onde, na maioria, ainda tinham papel importante ${ }^{16}$. O outro êxodo foi o internacional ${ }^{17}$,

Até porque a atividade de mineração de carvão no Sul de Santa Catarina, por estar sustentada na produção de carvão metalúrgico, vivia basicamente das benesses de um Estado regulador e autoritário.

Luiz Inácio Lula da Silva, candidato a Presidência da República pelo Partido dos Trabalhadores - PT, vencido nas eleições de 1990, no segundo turno.

${ }^{16}$ Foram trabalhar na agricultura, em pequenas propriedades de parentes que não tinham abandonado a atividade em busca de uma vida melhor na mineração de carvão.

Há com certa frequêencia notícias na imprensa catarinense que dão conta da migração de desempregados do Sul de Santa Catarina para os Estados Unidos. Em uma das últimas (Diário Catarinense, 01/07/2001:31) houve denúncia de um esquema de obtenção de visto com passaporte ilegal, de origem portuguesa em esquema de conexão com Governador Valadares (MG). 
que tem sido muito forte no Brasil contemporâneo e que assume expressividade em algumas cidades, entre elas Criciúma e região. ${ }^{18}$ É no começo da década de 1990, com a posse de Fernando Collor de Mello na presidência da República, que o setor carbonífero, viveu o seu pior momento. As privatizações iniciadas no governo da Nova República, de José Sarney, e aceleradas no governo Collor, somadas à desregulamentação da atividade, provocaram uma redução de $66,3 \%$ na oferta de vagas no mercado de trabalho, quando, em valores absolutos, houve uma redução de 9.103 postos de trabalho. Só a privatização da Carbonífera Próspera jogou na rua, em maio de 1990, mais de 1.570 mineiros $^{19}$. Foi nada menos do que $11,4 \%$ da força de trabalho empregada no setor em 1989, sendo o restante das demissões motivadas pela desregulamentação da atividade. Em Santa Catarina foram demitidos, em 1990, 47.268 trabalhadores, sendo 9.103 no setor carbonífero do Sul do Estado, 19,4\% do total. Se levarmos em consideração que o setor cerâmico do sul de Santa Catarina contribuiu com mais de 11,6\%, só esses dois setores na nossa região de estudo participaram com $31 \%$ do total.

Como solução a privatização da Carbonífera Próspera os trabalhadores propuseram a co-gestão como passagem para a constituição de cooperativa, mas a mesma não foi aceita pelo governo, que atendeu o lobby dos empresários do carvão, que não desejavam presenciar a existência de mais uma cooperativa de trabalhadores, como havia ocorrido com a CBCA em $1987^{20}$, e do próprio gover-

\footnotetext{
"Jornalista Eurico Ferreira Jr. (ex-DC) vive atualmente em Boston, Estados Unidos. Lá abriu um Jornal, o Brazil Today, após descobrir uma verdadeira mina para o ramo. Não são apenas os 200 mil emigrantes de GovernadorValadares (MG) que invadiram o estado, mas estão juntos com nada menos que 30 mil criciumenses e emigrantes de outras regiões do País. (...) o êxodo para os Estados Unidos tem uma só origem: a crise que há anos se abate na Região Sul do Estado, principalmente Criciúma, com a decadência da exploração do carvão. (...)". Diário Catarinense. $28 /$ 08/94:03.

19 O equivalente a $5,7 \%$ de todas as vagas fechadas em Santa Catarina no primeiro ano de Governo Collor, segundo S ANTOS, 2002.

"Em menos de um ano os trabalhadores já haviam tirado a empresa do vermelho e produziam 25 mil toneladas de carvão pré-lavado e $80 \mathrm{mil} \mathrm{t}$ de carvão bruto/mês. Nos sete meses de trabalho a administração reduziu ajornada de trabalho de 36 para 30 horas, adiantou o $13^{\circ}$ salário, incorporou todas as UR Ps aos salários e abriu duas novas minas, gerando mais de 200 empregos. Era a vitória da administração operária que funcionava através de uma comissão de mina eleita pelos mineiros. Esta
} 
no federal, que precisava mostrar logo de início aos bancos internacionais o seu comprometimento com a política neoliberal, mesmo tratando-se de uma empresa que tinha apresentado um lucro de 12 milhões de cruzeiros em $1989 .{ }^{2}$

Em 1999 o setor ofereceu 2.518 vagas, uma redução de 11.217 postos, ou de $81,7 \%$ em relação a 1989 , levando o setor carbonífera à posição inferior na oferta de emprego em 1999, dentre setores, como o cerâmico e o de base plástica (descartável e embalagens), que até então absorve menor número de trabalhadores, uma vez que o cerâmico empregava 4.614 e as indústrias de base plástica (descartáveis e embalagens) 4.202, ficando pouco acima do subsegmento de descartáveis plásticos (2.399).

Além da redução das vagas no mercado de trabalho, outra mudança que se percebeu foi em relação à sua distribuição entre as indústrias. Na década de 1980, as quatro maiores empregadoras eram a CCU, Criciúma, Próspera e CBCA, que foram, ao longo dos anos, aumentando sua concentração da mão-de-obra. Em 1980, elas absorviam $67,5 \%$ do total dos trabalhadores empregados nas indústrias carboníferas do Santa Catarina. O terceiro e o quarto lugar foram, na década de 1980, a Criciúma e a CBCA. O primeiro lugar quase sempre estava com a CCU e o segundo lugar com a Próspera, havendo anos em que elas trocavam de posição. Em 1990 as quatro maiores empregadoras já concentravam $82,2 \%$, quando a Próspera deixou de ser uma grande empregadora, passando de 26,6\%, em 1987 , para $8,7 \%$ em 1992 , ano em que iniciou uma lenta recuperação, chegando em 1989 com 20\% da mão-de-obra empregada no setor. A partir de 1990, começou uma redistribuição da mão-deobra, baixando a concentração de $82,2 \%$ entre as quatro maiores empregadoras para 64,2\% em 1995, sendo elas a Criciúma, Metropolitana, CCU e a Cooperminas, ex-CBCA. Na segunda metade da década de 1990 voltamos a contar com um aumento da concentração da mão-de-obra entre as quatro maiores empregadoras, na ordem de 73,1\% para 1999 , e com uma mudança das maiores empregadoras, com o fechamento da Nova Próspera e com a reativação das minas da Rio Deserto, que ocupou o lugar da CCU, ambas do Grupo Empresas Rio Deserto.

comissão se reunia a cada 15 dias e ali decidia todas as questões administrativas de cada mina", segundo CHOINACK 1, 1993:40.

C H O IN A C K I, 1993:44. 
Devemos registrar que em 1987, quando a CBCA passou para as mãos dos mineiros, ela absorvia $7,6 \%$ da mão-de-obra empregada no setor carbonífero. Tendo como proposta a não-demissão de seus colaboradores cooperados, foi aumentada sua participação no total da mão-de-obra até 1994, quando atingiu 19,6\%. A partir dali alguns de seus cooperados começaram a se aposentar, fazendo com que os índices de participação no número total de trabalhadores do setor viesse a cair. É importante registrar que ela é a carbonífera que paga os melhores salários do setor. Talvez essa seja a razão pela qual os empresários do carvão, de maneira geral, eram favoráveis ao fim da ex-CBCA, atual Cooperminas, e ao arrendamento das licenças de lavra a outra empresa, assim como foram contrários a que a Carbonífera Próspera experimentasse o mesmo processo.

Voltando ao desemprego entre os mineiros, é importante registrar que a recolocação dos mesmos no mercado de trabalho tem se tornado difícil; (i) porque a atividade não conseguiu recuperar os mercados perdidos, como o do carvão metalúrgico; (ii) o trabalho nas minas era a única formação profissional da grande maioria; (iii) os setores onde a exigência de qualificação profissional não é tão grande, como a construção civil, também entraram em crise, principalmente na região ${ }^{22}$; (iv) as condições de saúde do mineiro nem sempre permitiram o acesso em outra atividade ${ }^{23}$, além disso,

${ }^{22} "(\ldots)$ alguns foram e outros ficaram trabalhando de servente de pedreiro. (...) tem bastante desempregados. Há uns 15 dias atrás um mineiro desempregado da C C U veio aqui dizendo: olha, eu já vendi meu carro, já vendi um aparelho de som e eu não quero vender a única coisa que me resta, a minha casa.Vocês me ajudem a arrumar um serviço."Entrevista concedida pelo mineiro conhecido como Marinheiro, dentro da sede do Sindicato dos Mineiros de Criciúma, novembro de 1994. Apud. SANTOS, 1997:126-127.

${ }^{23}$ "A entrada em processo das grandes minas mecanizadas acarretou dois novos aspectos à mineração do carvão. As condições espaciais de trabalho melhoraram com a introdução de máquinas que exigiam maiores vãos, dando lugar em conseqüência, à abertura de galerias mais amplas. Foram ainda implantados sistemas de exaustão de ar mais potentes e o desmonte manual - pior tarefa para o mineiro — passou a ser realizado por grandes máquinas. Diante desses fatos, acreditou-se que estava sendo obtida uma efetiva melhoria nas condições de trabalho e que a mecanização estava vindo em beneficio dos mineiros.Acreditava-se ainda que as pequenas minas viriam a desaparecer dentro de um curto período de transição. Contudo, logo começaram a ser registradas, com maior intensidade, as doenças profissionais, especialmente nas minas de grande porte, em função dos volumes de carvão manejados e da circulação do ar dentro das galerias", segundo GOTHE, Carlos A., 1989:72. 
"(..) La Identidad dei mineiro con su actividad es tan fuerte, que el proyecto ${ }^{24}$ choca contra barreras culturales dificiles de tear $(\ldots)^{125}$

Para perceber a importância da atividade de mineração do carvão na economia regional, observe a Tabela 02 .

Tabela 02. Números totais de empregados das indústrias do sul de Santa Catarina

\begin{tabular}{lrcccr}
\hline Ano & Carvão & Cerâmico & Descartáveis plásticos & Embalagens & Total \\
\hline 1980 & 10.863 & 2.666 & 216 & 292 & 14.037 \\
1981 & 9.322 & 2.690 & 358 & 302 & 12.672 \\
1982 & 10.147 & 2.742 & 412 & 345 & 13.646 \\
1983 & $10.522^{(2)}$ & 3.142 & 389 & 331 & 14.384 \\
1984 & 10.898 & 3.086 & 436 & 357 & 14.777 \\
1985 & 10.536 & 3.228 & 538 & 405 & 14.707 \\
1986 & 9.794 & 7.853 & 703 & 458 & 18.808 \\
1987 & 9.169 & 8.633 & 653 & 513 & 18.968 \\
1988 & 12.785 & 13.464 & 592 & 590 & 27.431 \\
1989 & 13.735 & 12.998 & 544 & 650 & 27.927 \\
1990 & 4.632 & 13.566 & 729 & 806 & 19.733 \\
1991 & 4.412 & 8.063 & 880 & 849 & 14.204 \\
1992 & 3.453 & 6.771 & 925 & 868 & 12.017 \\
1993 & 4.207 & 7.003 & 995 & 980 & 13.185 \\
1994 & 3.615 & 7.013 & 1.127 & 1.198 & 12.953 \\
1995 & 3.505 & 6.619 & 1.476 & 1.439 & 13.039 \\
1996 & 2.330 & 5.112 & 1.849 & 1.576 & 10.867 \\
1997 & 3.034 & 4.937 & 1.778 & 1.709 & 11.458 \\
1998 & 2.709 & 4.781 & 2.056 & 1.659 & 11.205 \\
1999 & 2.518 & 4.614 & 2.399 & 1.798 & 11.329 \\
\hline
\end{tabular}

Fonte: Pesquisa direta, realizada em abril de 1999 e agosto de 2001.

(1) Posição de abril de 1999.

(2) Valor aproximado, por não terem sido publicados os valores oficiais.

Diante do exposto fica claro que a situação do trabalhador mineiro é muito delicada, pois ele não tem outra qualificação para ser absorvido no mercado de trabalho, não tem condições de saúde para buscar outra atividade, tendo que sofrer com a retração dos empregos de outros setores da economia regional, que conviver com sucessivas perdas salariais e ainda com a dificuldade de aceitação em outras atividades.

\footnotetext{
Trata-se do projeto de requalificação profissional da mão-de-obra mineira.

" Centro Itata - Centro Interdisciplinario de Estudios y Desarrollo Regional. El Desarrollo Regional desde el Mundo Social. Concepcion, Editora Anibal Pinto, 1992:76.
} 


\section{A relação capital $x$ trabalho}

A relação capital e trabalho está institucionalizada nos sindicatos ${ }^{26}$ e o grau de atrito pode ser medido pela relação entre o sindicato patronal e o sindicato dos trabalhadores. Por esta razão, antes de apresentamos as relações propriamente ditas, vamos conhecer o nível de sindicalização dos trabalhadores, o que já nos dará um bom indicativo.

É oportuno dizer que há no Brasil, mais precisamente nos países industrializados, sobretudo nos desenvolvidos, um movimento de enfraquecimento dos sindicatos, provocado principalmente pelo desemprego, pela terceirização, pelas inovações organizacionais e tecnológicas e pela precarização do trabalho, fruto do neoliberalismo, como apontou diversos estudos, entre eles ALVES ${ }^{27}$, ZAPATA ${ }^{28}$ e ANTUNES ${ }^{29}$. O que vamos ver aqui é se esse movimento de dessindicalização já atingiu nossa região de estudo.

No setor carbonífero, na base sindical do Sindicato de Rio Maina, em 1984 havia 3.322 empregados, com 1.805 sindicalizados, ou seja, 54\%, e no de Criciúma havia 3.000 operários com 1.600 sócios, sendo, portanto $53 \%$ deles sindicalizados. Em 1989 o "índice de sindicalização dos mineiros, (...) ultrapassava os $50 \% \%^{30}$, não havendo alterações significantes para o ano de 2001 , pois o mesmo estava em $54,3 \%$, sempre de mineiros da ativa, muito embora tenha havido uma proliferação de sindicatos ${ }^{31}$, com a criação em Lauro Müller, Siderópolis e Urussanga. O singular no sindicato dos mineiros é que há um número muito grande de mineiros aposentados sindicalizados, representando os mineiros em atividade menos de $10 \%$ do total de associados. Isto deve-se (i) às condições de saúde precária

\footnotetext{
Embora elas também ocorram no chão da fábrica, por exemplo.

ALVES, apud.TEIXEIRA \& OLIVEIRA, 1998:109-111.

ZAPATA, 1994

ANTUNES, 2000, sobretudo os capítulos "Dimensões da Crise Contemporânea do Sindicalismo: Impasses e Desafios" e "Mundo do Trabalho e Sindicatos na era da Reestruturação Produtiva: Impasses e Desafios do Novo Sindicalismo Brasileiro".

VOLPATO, 1989:295.

Hoje, na região carbonífera de Santa Catarina há um único sindicato patronal e cinco de mineiros, com sedes em Criciúma, Rio Maina, Lauro Müller, Siderópolis e Urussanga. Esse movimento de aumento do número de sindicatos no Brasil após a abertura política também foi estudado por ANTUNES, op. cit.
} 
com que o mineiro chega à aposentadoria, apesar de se aposentar com 15 anos de trabalhos no subsolo, (ii) ao caráter assistencialista a que foram levados os sindicatos, em especial após o golpe militar de 1964, e (iii) à falência do sistema público de $\mathrm{saúde}^{32}$, que obriga o mineiro aposentado a continuar sindicalizado para ter complementação de atendimento médico-odontológico, oferecido pelo sindicato.

Apesar de não termos conseguido levantar uma série histórica da taxa de sindicalização dos trabalhadores do carvão, pois os sindicatos envolvidos não possuíam levantamento sobre o número de associados durante os anos das décadas de 1970, 1980 e 1990, podemos afirmar que ela é alta no Sul de Santa Catarina, se comparada com a sindicalização como um todo em alguns países, como demonstrou a Tabela 03, elaborada a partir de ANTUNES ${ }^{33}$, uma vez que a média de sindicalização no setor carbonífero é de $54,3 \%{ }^{34}$.

Podemos também afirmar que não está ocorrendo, como em outros locais onde a política econômica é neoliberal, o processo de diminuição da taxa de sindicalização ${ }^{35}$. A taxa era de $54 \%$ em 1984 , ultrapassava os $50 \%$ em 1989, voltando para os 54,3\% em 2001 , como já comentamos. Como não existe no Brasil estudo que dê conta de demonstrar a evolução da taxa de sindicalização, não podemos afirmar se esta tendência se repita em outros setores.

Por outro lado, a relação entre patrões e empregados, é de muito conflito. O volume de atritos entre essas duas classes sociais é mediado por uma série de fatores, entre eles o grau de liberdade democrática da sociedade e o nível de organização da classe trabalhadora. Historicamente os mineiros têm se mostrado um grupo social extremamente combativo, fruto do tipo de trabalho duro e que exige solidariedade ${ }^{36}$.

"(...) em 1920, Criciúma já teve sua primeira greve de mineiros, apenas um ano após o embarque da primeira leva de carvão extraído na cidade. Foi um movimento incentivado pelos ideais

VOLPATO, 1989:295-296.

2000:68.

SANTOS, 2002 .

Este fenômeno também foi estudado por ANTUNES, 2000.

SANTOS, 2002. 
anarquistas que fervilhavam pela Europa e que chegavam ao país junto com os imigrantes".

Tabela 03. Taxa de sindicalização (países selecionados) $1988^{\text {"1) }}$

\begin{tabular}{lc}
\hline País & Taxa de \\
\hline França & 12,0 \\
Espanhacallização (\%) \\
Estados Unidos & 16,0 \\
Turquia & 16,8 \\
Grécia ${ }^{(2)}$ & 18,8 \\
Países Baixos & 25,0 \\
Suíça & 25,0 \\
Japão & 26,0 \\
Portugal (2) & 26,8 \\
Alemanha & 30,0 \\
Canadá & 33,8 \\
Itália & 34,6 \\
Reino Unido & 39,6 \\
Austrália & 41,5 \\
Áustria & 42,0 \\
Luxemburgo & 45,7 \\
Nova Zelândia & 49,7 \\
Irlanda & 50,5 \\
Bélgica & 52,4 \\
Noruega & 53,0 \\
Finlândia & 55,1 \\
Dinamarca & 71,0 \\
Holanda & 73,2 \\
Suécia & 78,3 \\
\hline
\end{tabular}

Fonte: ANTUNES, 2000:68

Obs.:

(") Com as exceções de Holanda, 1989; Irlanda, 1987; Luxemburgo, 1989; Nova Zelândia, 1990; Espanha, 1985; Suíça, 1987; Turquia, 1987.

(2) As taxas referentes a Portugal e Grécia são por estimativa.

Segundo VOLPATO ${ }^{38}$, é o perigo vivido nas minas, o trabalho duro e a solidariedade forjada na luta que propiciaram a história de combatitividade dos trabalhadores nas minas de carvão do Sul de Santa Catarina. Essa organização sindical, estudada por ela, passou por diversas fases e sofreu diversas ações de cooptação por parte dos mineradores $^{39}$. Algumas vezes a cooptação era violenta, forte e hu-

${ }^{37}$ S A N T OS GUGLIELMi In: SILVA JR., 1998: 218.

${ }^{38} 1984: 110-145$ e 1989:268-301.

${ }^{39}$ Além das razões conhecidas para cooptar a classe trabalhadora, os mineradores 
milhante, como as que se procederam durante o período da ditadura militar, e outras vezes ela era subliminar, camuflada.

Embora desde o início da exploração do carvão as relações entre capital e trabalho já fossem conflituosas, com greve de mineiros já em $1920^{40}$, a criação do sindicato da categoria só foi ocorrer em 1945. Em 1944 é criada a Associação dos Mineiros, que no ano seguinte é transformada em sindicato, dentro da política do Estado brasileiro de sindicalizar a classe trabalhadora, visando fortalecer o Governo de Getúlio Vargas, enfraquecido pelos ventos democráticos que sopravam mundo afora com o fim da II Guerra Mundial ${ }^{41}$.

Assim, os sindicatos tutelados pelo Estado ${ }^{42}$ serviram aos propósitos dos mineradores, de esfriamento da luta de classe, com eleição

possuíam mais uma. Por isso, os mineiros, através do sindicato, foram usados por diversas vezes como massa de manobra dos mineradores, com o intuito de auferirem ganhos através da valorização do preço do carvão. Muitas das greves serviam ao interesse de mineiros e mineradoras, isto até a desregulamentação da atividade, uma vez que "(...) Todo reajuste ou aumento salarial era precedido por um aumento no preço do carvão, tabelado pelo governo federal e comprado pelas empresas estatais. Os mineiros em greve, organizavam comissões de viagem ao Rio de Janeiro, juntamente com os mineradores, para pressionar as autoridades a reverem a política de preços do carvão nacional. Os mineiros tinham muito interesse na elevação do preço do carvão pois recebiam os salários baseados na produção e nos custos do produto. As greves tinham dupla função: exercer pressão sobre a classe patronal e garantir vantagens para os mineiros e, paradoxalmente, favorecer a classe patronal em seus interesses de lucro." (Ata da Assembléia Geral, 1963, 8/3)," Segundo VOLPATO, $1989: 279 / 280$.

"Segundo SILVA JR., 1998:218.

VOLPATO, 1984:110-111.

"A legislação trabalhista adotada pelo governo [Vargas] inspirou-se em razões políticas. Ela foi proposta e aplicada com o objetivo precípuo de sistematizar e formalizar as relações políticas entre as classes sociais urbanas. Em especial, tratava-se de pacificar as relações entre os vendedores e compradores de força de trabalho no mercado urbano (setores secundário e terciário).

Desde a Primeira Guerra Mundial haviam se intensificado os movimentos e as lutas operárias. Entretanto, o governo e os compradores de força de trabalho pouco se interessavam pela institucionalização dos direitos e obrigações nas relações políticas e econômicas entre empregados e empregadores. Aliás, até 1930 predominava no governo entre os compradores de força de trabalho quase que a mesma concepção oligárquica de poder e mando característica da sociedade agrária de então. Essa era a razão por que antes da Revolução de 1930 as leis trabalhistas eram principalmente leis repressivas". Segundo IANNI, 1996: 45-46 e 49. 
de diretoria pelega $\mathrm{a}^{43}$, amenizadora dos conflitos. "Os primeiros tempos foram difíceis; (...) $O$ primeiro presidente foi indicado pelos mineiros. Depois (...), a classe patronal passou a indicar candidatos e conseguia elegê-los"." Essa situação perdurou por mais de uma década, uma vez que "As diretorias dos sindicatos, desde sua fundação em 1945 até 1957, foram constituídas por 'lideranças pelegas'". ${ }^{45}$ Quando o sindicato foi criado, existia um movimento trabalhista autêntico, que se reunia às escondidas e que fora tomado de surpresa, ficando perplexo com a iniciativa de criação do sindicato pelo Estado ${ }^{46}$, e acabou ficando de fora do sindicato por todo esse período.

"O movimento trabalhista autêntico crescia, dificultando as lideranças oficiais do sindicato. Esta situação levou a diretoria do sindicato a renunciar coletivamente, em Assembléia Geral realizada em 16 de dezembro de 1956. Na mesma ocasião se procedeu a 'escolha dos membros que irão compor a Junta Governativa provisória'.

Em 15 de dezembro de 1957, procedeu-se à eleição para a diretoria do sindicato. (...) Pela primeira vez, as lideranças apontadas pelos trabalhadores saem vitoriosas nas eleições." 47

A chapa autêntica era encabeçada por Antônio José Parentte ${ }^{48}$ que com seus companheiros inaugurou uma nova fase do Sindicato dos Mineiros de Criciúma, que vai de dezembro de 1957 até o dia 10 de abril de 1964, quando o golpe militar prendeu toda a diretoria do sindicato e alguns mineiros, totalizando 42 trabalhadores. Neste período a greve foi um instrumento de pressão dos mineiros utilizado em quase todos os anos, sendo deflagradas em 1958 (18 dias),

4 Segundo depoimento de Jorge Feleciano, Apud.VOLPATO, 1984:114.

${ }^{44}$ Afirma omineiroaposentado ManoelRibeiro, Apud.VOLPATO, 1984:112.

45 Mineiros aposentados, Apud.VOLPATO, 1984:112.

“VOLPATO, 1984:111.

VOLPATO, 1984:112-113.

48 "Aquele, agitava! Estava fichado como torneiro-mecânico na C B C A, mas ocupava o cargo de presidente do Sindicato dos Mineiros de Criciúma.Já havia sido reeleito e contava com o apoio de seus assessores, os Fininhos, além de prestigiado por todos os trabalhadores do carvão na região carbonífera. Gostava de peitar os mineradores, em defesa do que ele consideravajusto para os mineiros", segundo SILVAJR., 1998: 218 . 
1959 (18 dias), 1960 (24 dias), 1961 e 1963 (8 dias) ${ }^{49}$, tendo sido a de 1960 a mais acirrada. Ela foi iniciada pelos mineiros da Metropolitana, recém adquirida por Santos Guglielmi e Diomício Freitas. A provável ausência de greve em 1962 e a fraca greve de 8 dias em 1963 devem-se à criação do Sindicato em Rio Maina,como veremos adiante. Sobre a greve de 1960, relata Santos Guglielmi, um dos maiores mineradores do Sul de Santa Catarina:

"Tão logo assumimos a Carbonífera, (...) uma greve explodiu na cidade. Uma lista de reivindicação nos foi apresentada. Os sindicalistas exigiam reajustes nos salários e maior segurança nas galerias onde extraíam o carvão. (...) As bocas-de-minas da Metropolitana, (...) foram bloqueadas pelos grevistas. Para manter alguma produção, mandamos nossos caminhões para a mineração Visconde, na Linha Batista, do outro lado da cidade. Só que não pudemos trabalhar com eles, já que os sindicalistas haviam organizado um bloqueio na estrada que levava até a Visconde. No caminho, (...) as famílias dos quase 500 mineiros da Metropolitana deitaram no chão e fizeram nossos caminhões voltar. Para contornar aquela crise, Diomício Freitas pediu auxílio em Florianópolis. Tropas do exército foram designadas para manter a ordem. Os mineiros entraram em conflitos." ${ }^{50}$

Sobre a mesma greve, um mineiro, em entrevista a VOLPATO, descortina outros fatos e apresenta o quadro com outras tintas:

"A greve que ocorreu em 1960 foi a mais ferrenha da história sindical de Criciúma. Houve muita repressão. A greve nasceu na Metropolitana e se estendeu a todas as mineradoras. Para reprimir, veio o exército na rua, com cacetetes, bombas de gás lacrimogêneo, etc. Na Próspera, tiveram que fazer piquetes cercando caminhões que levavam mineiros à mina de Urussanga. Os piquetes eram formados pelas mulheres dos mineiros, que se deitavam no meio da estrada; havia mulheres grávidas deitadas no meio da rua, para impedir a passagem dos caminhões que levavam trabalhadores. A participação das mulheres resguardava os

"9 VOLPATO, 1984: 114-116.

SANTOS GUGLIELMI, In: SILVA JR., 1998: 219-221. 
trabalhadores, mais facilmente expostos aos desmandos dos patrões e exército. Foi uma paralisação de 28 dias. Em contrapartida, houve represália das empresas. Só da Metropolitana foram demitidos mais de 50 mineiros, alguns com estabilidade". ${ }^{51}$

Podemos perceber que, nas duas falas acima (SILVA J R., 1998:218 e VOLPATO, 1984:110-111), a participação das mulheres nas lutas dos mineiros era uma prática adotada pela categoria. Na greve de 1960 ela ocorreu diversas vezes, entre elas, para impedir o trabalho nas minas da Metropolitana ${ }^{52}$ e da Próspera ${ }^{53}$, e foram utilizadas em diversas outras greves, como forma de proteger seus maridos dos desmandos e represálias, como a ocorrida na Metropolitana, em 1960, com demissões. Essa organização sindical, com espírito de luta e combatitividade, forjada dentro das minas, subiu as galerias, desceu as ruas e penetrou em outras categorias, que se espelhavam nos mineiros, fazendo com que o movimento sindical de nossa região de estudo passasse a ser reconhecido em todo Estado e até em algumas regiões do Brasil, levando também a ganhos salariais, se comparando com as mesmas categorias em outras partes do país ${ }^{54}$. Esse reconhecimento à combatividade gerou até dificuldades de relocação no mercado de trabalho.

As estratégias dos mineradores para conter a luta dos trabalhadores por melhores salários e condições de trabalho foram desde a apresentação de chapa pelega para concorrer ao sindicato, o uso da força do Estado para substituir diretorias autênticas e combativas por interventores de interesse dos mineradores, chegando até à divisão do Sindicato dos Trabalhadores na Indústria de Extração de Carvão

VOLPATO, 1984:117-118.

SILVA JR., 1998:219-224.

VOLPATO, 1984:117-118.

"Informações que transitam entre a classe patronal fortalecem a política adotada pelos empresários locais de resistirem à contratação de mineiros. Após levantamento feito em indústrias metalúrgicas e têxteis do norte do Estado, procurando as causas da mudança da política sindical das categorias antes 'ordeiras' e 'cumpridoras de suas funções', e atualmente incentivando as greves e estimulando 'prática desordeiras', constatou-se que os líderes da nova política não eram 'gente da casa' mas 'pessoal do Sul do Estado'. Conclusão que passou a orientar o recrutamento de pessoal das empresas, no sentido de recusar os candidatos do Sul do Estado, além da decisão tomada de demitir 'oportunamente' os 'baderneiros'". Segundo VOLPATO, 1989:242 (nota 06). 
de Criciúma, com a criação do Sindicato dos Trabalhadores na Indústria da Extração de Carvão do Rio Maina, distrito de Criciúma, distantes 9 quilômetros um do outro e dentro de uma mesma base sindical, que segundo a legislação deve ser no mínimo a área de um município.

"Após a vitória eleitoral efetuada em 28 e 29 de outubro de 1961, os empresários, liderados por Diomício Freitas, então candidato e deputado federal, procuraram sensibilizar o governo e influir politicamente no Ministério do Trabalho, para obterem criação de outros sindicatos no município de Criciúma".55

Dentre essas estratégias para "domesticar" a classe trabalhadora, encontramos ainda a criação de times de futebol, que obteve, durante um certo tempo, um resultado eficiente, do ponto de vista do capital. Os mineradores aproveitaram-se do fato de que após a $\mathrm{Se-}$ gunda Guerra Mundial os mineiros organizaram-se por boca-demina para comporem seus times de futebol e disputarem partidas nos finais de semana. Com o passar do tempo os mineiros foram estimulados à formação dos times não mais por boca-de-mina, mas por empresa carbonífera, sendo inclusive criada uma Liga Amadora que promovia os torneios. Percebendo a paixão dos mineiros pelo futebol, alguns empresários começaram a investir na atividade, como forma de cooptar os trabalhadores. A Carbonífera Próspera investiu no Próspera, a CBCA no Atlético Operário e a Metropolitana no Esporte Clube Metropol.

"O Metropol, em 15 anos de atividade, nunca havia ganho nenhum título. A coisa começou a mudar em 1960, um ano após adquirirmos a Carbonífera Metropolitana. Eu e Diomício Freitas éramos presidentes-de-honra do clube, enquanto Dite Freitas e meu filho Realdo (...) detinham o cargo de patronos.

Foi um investimento tremendo para fazer do Metropol uma

\footnotetext{
${ }^{55}$ SegundoJaime Zanatta, ex-presidente da A C IC e na época presidente da FACISC, A pud. TEIXEIRA, 1995:198, os salários dos ceramistas, metalúrgicos e vestuaristas do Sul de Santa Catarina em relação aos de São Paulo eram favoráveis aos catarinenses em $85,2 \%, 166,1 \%, 97,6 \%$ respectivamente. Os salários dos mineiros do Sul de Santa Catarina eram, em comparação aos dos mineiros do Rio Grande do Sul, estado vizinho, 47,1\% maiores.
} 
equipe competitiva. Em dez anos de atividade, o time foi duas vezes campeão da LARM, cinco vezes campeão catarinense, duas vezes campeão sul-brasileiro e participou várias vezes da Taça Brasil. Jogava e vencia de times como Grêmio, Botafogo, Curitiba, Atlético Mineiro, Inter de Porto Alegre. (...) E os mineiros, que antes eram revoltosos, passaram a adorar aquela coisa do Metropol vencer, vencer, vencer. Após o golpe militar, em 1964, com o Governo perseguindo os comunistas, nunca mais tivemos problemas com greves. (...) No fundo, o Metropol (...) colaborou na campanha eleitoral que levou meu sócio Diomício Freitas a uma cadeira de deputado federal, em 1962, logo após o Metropol voltar da Europa." 56

Se durante o regime militar, por razões óbvias, as empresas não precisavam mais "investir tanto dinheiro em diversos, em futebol", afinal, "aquele pessoal estava ali era para trabalhar, não para jogar bola"57, com a abertura política, o incentivo à prática desportiva, em defesa das cores e bandeira de sua carbonífera, voltou a ser utilizado. Um exemplo é a Carbonífera Criciúma, que mantém modalidade de futebol adulto e infantil.

"(...) hoje nós somos tri-campeões da Liga Amadora de Futebol. Meus funcionários, eu não contrato profissionais para jogar, são todos empregados da empresa. Nós temos também um time de crianças que a carbonífera mantém, são 70 e poucas crianças, sendo filhos de 11 funcionários, que disputam inclusive o Moleque Bom de Bola." ${ }^{58}$

Algumas das lutas mais acirradas depois da redemocratização do Brasil foram (i) a de 1987, que envolveu os mineiros em luta pela manutenção dos empregos da CBCA, que resultou na Cooperminas, a cooperativa de mineiros que assumiu a mineradora ${ }^{59}$, e (ii) a de 1990, em torno do sucateamento e privatização da Carbonífera

VOLPATO, 1984:121.

S A N T OS GUGLIELM1, In: 1998:224, 226 e 227.

SANTOS GUGLIELMI, In: 1998:226.

Segundo entrevista direta, realizada no dia 29/05/2000, com o senhor Alfredo Flávio Gazzola, Diretor Administrativo e Industrial da Carbonífera Criciúma S/A. 
Próspera. A greve na CBCA foi motivada pelo atraso nos salários e pela falta de recolhimento dos encargos sociais ${ }^{60}$, apesar de terem ocorrido outras greves, algumas bem longas, como a de $1996^{61}$, de 50 dias.

"No dia 25 de junho a greve [contra a desativação/privatização da Próspera] fez 51 dias e os mineiros decidem por manobras mais radicais do que reuniões e reinvidicações: Acampam no pátio de manobras da Rede Ferroviária Federal S/A. Antes, organizam uma caminhada até a rede ferroviária, da qual participam mil pessoas. Lá dentro eles decidem bloquear o transporte do carvão. (...) Os mineiros radicalizam e destroem parte dos trilhos bloqueando definitivamente a estrada de ferro. (...)

A polícia invade o acampamento montado no pátio da RFFSC, destrói os barracos. Os mineiros reagem com paus e pedras fazendo a PM recuar. (...)

Dois dias depois a polícia volta ao acampamento tentando desalojar os mineiros. Os mineiros revidam. Mais de três mil pessoas armam barricadas, bloqueiam ruas e jogam pedras. É uma verdadeira guerra campal. Os políticos negociam, a PM vai embora, mas já não dá mais para deter a raiva surda que cresce entre os mineiros. Enfurecidos eles quebram seis carros da polícia, 25 pessoas saem feridas do conflito". ${ }^{62}$

\footnotetext{
${ }^{60}$ Quando foi decretada a falência da C B C A em agosto de 1987 o Sindicato dos Mineiros de Criciúma assumiu a massa falida, dando início à primeira cooperativa de mineiros de carvão do Brasil.

${ }^{6}$ "As confusões envolvendo a C B C A começaram em março de 1987. Foram descobertas fraudes nas companhias de Álvaro Catão, então dono da C B C A e da Barro Branco. As fraudes montavam 538 milhões de cruzados. É que as empresas não recolhiam impostos, FGTS, lapas e Imposto de Renda, há mais de 12 anos. (...) 1.400 trabalhadores estavam sem salários e exigiam seus direitos. (...) em abril, tanto a Barro Branco como a C B C A entram com pedido de concordata", segundo C H O I N A C K I, 1993:36 e 37.

${ }_{62}$ "Cerca de 400 mineiros da Nova Próspera voltam ao trabalho hoje. Depois de 50 dias de greve, os trabalhadores aceitaram a proposta da mineradora em assembléia ontem à tarde na sede do Sindicato dos Mineiros. Os trabalhadores ganharam $17 \%$ de reajustes, nove dias do mês de março em vale-mercado, 50\% das férias e folga aos sábados com compensação durante a semana. Esta proposta também foi aceita em assembléia no último sábado pelos mineiros da CCU,Treviso, Criciúma e Metropolitana. Segundo o presidente do Sindicato dos Mineiros Ivan Westthal os mineiros saíram perdendo nesta greve. Ele explicou que os trabalhadores ficaram muitos dias
} 
Assim, desde o início da atividade de exploração de carvão, as lutas de classe já eram tensas. Num primeiro momento, a estratégia dos mineradores era a de contratar empreiteiras para explorar suas minas. Se estas não conseguissem cumprir os contratos por qualquer motivo que fosse, simplesmente os mineradores trocavam de empreiteira. Depois vieram as diversas formas de cooptação, que passaram pela formação de direção do sindicato pelega e até pelo patrocínio de equipes de futebol de mineiros. Depois do breve período de militância e lideranças autênticas veio o golpe militar de 1964.

"(...) estabeleceram-se novas normas para o exercício do direito de greve, aposentadoria, assistência médica, estabilidade no emprego etc. A 'paz social', por exemplo, foi definida como 'requisito fundamental da segurança nacional'. Em conseqüência, a 'greve proibida', ou deflagração de modo ilegal, passou a ser considerada como atentatória à segurança nacional. (...)

Em conseqüência (...) o sindicato perdeu até mesmo a sua função básica de órgão de reivindicação salarial. Os percentuais de aumento salarial passaram a ser estabelecidos pelo Conselho $\mathrm{Na}$ cional de Política Salarial, segundo os índices de crescimento da produtividade e os resíduos inflacionários calculados pelo Conselho Nacional de Economia e o Conselho Monetário Nacional. (...)

Procurou-se acentuar o caráter assistencial e recreativo do sindicato, em detrimento da sua função política." ${ }^{63}$

Hoje o desemprego e a precarização do trabalho patrocinados pelo neoliberalismo dão a sua contribuição ao esfriamento das lutas sindicais no mundo todo. Os estudos sobre o movimento sindical têm apontado uma significativa redução das greves, tanto em sua quantidade quanto em sua intensidade. Se a taxa de sindicalização ainda não foi atingida, muito em virtude das atribuições assumidas pelos sindicatos durante o regime militar e mantidas na abertura, como atendimento médico-odontológico, bolsas de estudo etc, as lutas estão arrefecidas, com sensível redução no poder de barganha

parados para voltar com índice de aumento baixo", SegundoJornal da Manhã, 03/ 04/1996:5.

${ }^{63}$ C H O I N A C K I, 1993:38. 
da classe trabalhadora, que se vê pressionada pelo exército industrial de reserva, como podemos constatar em depoimentos de empresários em nossa região de estudo e um de mineiro, líder sindical, transcritos abaixo:

"Por outro lado, o desemprego que se instalou nesse país, que foi alto e continua sendo algo de terrível, tem restringido muitas as ações por parte do sindicato. Hoje uma ação sindical em termos de reivindicações leva muito mais em consideração a manutenção do emprego, ou a ampliação da quantidade de empregos, que reivindicações salariais e outros tipos de reivindicações que aumentem os custos para as empresas."

"(...) o mineiro perdeu muito, mas ele não quer perder o trabalho, ele perdeu o salário mas ele quer ficar empregado. Se ele ganhava 8 ou 9 salários mínimos nos anos de 84, 85 por aí, hoje ele tá com 4 salários mas ele quer ficar empregado porque é o que ele muito fez e o que ele sabe fazer é tirar carvão. Como o salário já é pouco não quer que feche uma mina porque ele quer se aposentar." ${ }^{65}$

Atualmente, como vem ocorrendo com quase todo o movimento operário no Brasil, as lutas têm sido muito mais para manutenção do emprego que por conquistas salariais e/ou sociais, e essa situação é geral, haja vista as declarações de Luiz Marinho, presidente do Sindicato dos Metalúrgicos do A B C paulista, que disse que "o sindicato, (...) concorda em fazer concessões, como reduzir jornada de trabalho e salários com compensação de renda, isto é, alguma coisa como bônus ou participação nos lucros que complementa o salário, mas não implica encargos ${ }^{\prime \prime 6 \sigma}$, que é uma forma de flexibilização camuflada, pois consiste numa fórmula para escapar dos encargos sociais.

Essa situação gera uma falsa "harmonia", que é externalizada no discurso de um bom número de representantes das empresas.

${ }^{64}$ I A N N I, 1996:276-284.

${ }^{65}$ Gerson Lisboa Garcia, diretor-superintendente da Carbonífera Catarinense S/A, em entrevista direta, realizada em $01 / 06 / 2000$.

${ }^{66}$ Revista Isto É. ${ }^{\circ} 1516,21 / 10 / 1998: 32$. 


\section{Os salários}

O salário do mineiro na região Sul de Santa Catarina é composto de um piso salarial, produtividade e horas-extras. A média anual de salário-base em número de salários-mínimos tem gravitado em torno de 3,2 salários mínimos, sendo a média mais baixa em 1995, de 3,07 , e a mais alta em 1997, de 3,4, como pode ser observado na Tabela 04 .

Tabela 04. Média anual do salário-base em número de salários-mínimos do setor carbonífero - SM

\begin{tabular}{lcccccc}
\hline Empresa & 1994 & 1995 & 1996 & 1997 & 1998 & 1999 \\
\hline Cooperminas & 3,71 & 3,14 & 3,66 & 3,98 & 3,67 & 3,38 \\
Ibramil & 3,52 & 3,37 & 3,52 & 3,58 & - & - \\
Belluno & - & - & - & 3,64 & 3,56 & 3,50 \\
Metropolitana & 3,40 & 3,24 & 3,21 & 3,45 & 3,38 & 3,29 \\
c c u * & 3,31 & 3,13 & 3,30 & - & - & - \\
Catarinense & 3,30 & 3,15 & 3,28 & 3,34 & 3,31 & 3,23 \\
Criciúma & 3,29 & 3,14 & 3,29 & 3,35 & 3,31 & 3,23 \\
Barro Branco & 3,31 & 3,14 & 3,28 & 3,34 & - & - \\
Treviso & 3,28 & 3,12 & 3,12 & 3,56 & 3,28 & - \\
Cocalit & 2,23 & 2,20 & 2,30 & 2,35 & 2,30 & 2,24 \\
\hline Média & 3,26 & 3,07 & 3,22 & 3,40 & 3,26 & 3,15 \\
\hline
\end{tabular}

Fonte: Elaborado a partir de dados fornecidos pelo SIECESC.

Obs.: * A Rio Deserto é a sucessora da CCU.

A análise da Tabela acima permite algumas considerações:

a) A Cocalit, historicamente, é a carbonífera que tem pago salários muito abaixo da média do setor. Enquanto a média do setor foi de 3,2, como vimos, a da Cocalit foi de 2,27, representando uma diferença de $30 \%$ no piso daqueles trabalhadores;

b) Além da Cocalit, as únicas indústrias carboníferas que em nenhum momento figuraram entre as três melhores pagadoras, nos anos selecionados, foram a Treviso, Criciúma e Barro Branco;

c) A empresa que maior piso salarial ofereceu foi a Cooperminas, ex-CBCA, que, como já havíamos comentado, é administrada pelos empregados, organizados em cooperativa, desde 1987. Talvez este seja um dos medos dos mineradores em relação ao fato dos empregados terem assumido a CBCA. Ter em mãos o processo produtivo, os custos e as rendas de produção pode ser uma boa arma na hora das negociações salariais, o que na prática não tem ocorrido; vale a pressão do exército industrial de reserva existente no setor; 
d) Talvez por tratar-se de indústria criada recentemente, em operação a partir de 1997 e levando em consideração, além desse ano, somente os de 1998 e 1999, a Belluno ocupou a segunda posição entre as de melhor piso salarial, perdendo só para a Cooperminas.

TABELA 05. Classificação dos salários dos mineiros

\begin{tabular}{cc}
\hline Salário-mínimo recebido & Mineiros $(\%)$ \\
\hline $2-3$ & 35 \\
$3-5$ & 35 \\
$5-7$ & 20 \\
$7-10$ & 10 \\
\hline
\end{tabular}

Fonte: Citado por VOLPATO, 1989:214.

Levando em consideração o piso salarial, as horas-extras e a produtividade, que consiste no excedente que o mineiro extrai, além de sua cota previamente estipulada, durante a década de 1980, os salários recebidos pelos mineiros poderiam chegar até dez saláriosmínimos, sendo que $70 \%$ recebia entre dois e cinco salários-mínimos (v. Tabela 05). "O mineiro especializado do subsolo da Carbonífera Metropolitana tem um salário médio da ordem de Cr\$14.000,00/mês, que representa uma remuneração elevada em termos de trabalhador brasileiro ${ }^{4{ }^{* 7}}$, eqüivalendo a pouco mais de cinco salários-mínimos, isto em janeiro de 1980. Na década de 1990 a realidade já era outra, e os salários foram bastante aviltados ${ }^{68}$, muito embora ainda se mantivessem acima da média da remuneração dos trabalhadores catarinenses, como pode ser constatado na Tabela 06 , que registra que 65,7\% dos trabalhadores catarinenses ganham menos de 5 salários-mínimos.

Além da perda de vagas no mercado de trabalho, das dificuldades de requalificação profissional e do acesso ao emprego em outros ramos da economia regional, o mineiro também viu seu salário encolher e hoje vive pressionado pelo exército industrial de reserva, que tem mudado, e em muito, sua combatividade sindical, o que tem gerado o rebaixamento das rendas do trabalho.

"Em termos comparativos, atualmente, a renda familiar dos trabalhadores na indústria do carvão, em Criciúma, está muito aci-

${ }^{67}$ GU GLIELMI, 1980:20. Revista IS TO É, n 1677, 21/11/2001:81.

${ }^{68}$ Revista IS TO É, n ${ }^{\circ} 1677,21 / 11 / 2001: 81$. 
ma da renda familiar dos trabalhadores das indústrias cerâmicas da região, e também da dos assalariados em geral no Brasil, na área urbana. (...)

Os salários nas carboníferas se constituem, pois, em incentivos para o recrutamento de mão-de-obra, compensando os riscos e as difíceis condições de trabalho existentes na indústria extrativa do carvão" ${ }^{69}$.

Tabela 06. Trabalhadores da extração mineral por faixa de remuneração, em salários-mínimos (média anual) — Santa Catarina — 1996

\begin{tabular}{cr}
\hline Faixa de remuneração (em salários-mínimos) $($ em \%) & Extrativa Mineral \\
\hline 0 a 0,5 & 1,24 \\
Mais de 0,5 a 1 & 10,18 \\
Mais de 1 a 2 & 12,48 \\
Mais de 2 a 3 & 20,11 \\
Mais de 3 a 4 & 21,69 \\
Mais de 4 a 5 & 21,35 \\
Mais de 5 a 7 & 7,27 \\
Mais de 7 a 10 & 3,13 \\
Mais de 10 a 15 & 0,94 \\
Mais de 15 a 20 & 1,19 \\
Mais de 20 & 0,44 \\
Ignorado & 4.127 \\
\hline No total de trabalhadores & \\
\hline
\end{tabular}

Fonte: RAIS, 1996 (economia formal). Elaboração: DlEESE-SC, 1999:81.

\section{0 faturamento por empregado}

O faturamento por empregado na indústria carbonífera também sofre, assim como a produtividade da mão-de-obra, oscilações muito grandes, que nos obrigaram a relativizar sua importância como objeto de análise, pelo fato de uma indústria carbonífera possuir

"Os mineiros da Carbonífera Próspera permaneceram 40 dias parados quando a companhia foi incorporada a CSN do Rio de Janeiro, que não cumpriu a decisão do Tribunal Regional do Trabalho que concedera $145 \%$ de reajuste salarial. A C N pagou apenas $79 \%$, que coincidia com os cálculos de reposição salarial do governo. Os mineiros em greve reivindicavam a equiparação salarial. Historicamente a Carbonífera Próspera mantinha uma classificação hierárquica de trabalhadores na produção, melhor remunerados que os de outras companhias. Pela primeira vez os mineiros desta empresa estavam em desvantagem salarial frente aos demais. Isto motivou a deflagração da greve de todos os trabalhadores da Próspera", segundo VOLPATO, 1989:297. 
várias bocas de minas, com estágios tecnológicos diferenciados, e de possuir diferentes tipos de exploração (mina a céu aberto e/ou de galeria). A Carbonífera Metropolitana, nos sete anos estudados (apresentados na Tabela 07), ficou entre as quatro com maior faturamento/homem.

Tabela 07. Faturamento por empregados das indústrias carboníferas do sul de Santa Catarina

\begin{tabular}{|c|c|c|c|c|c|c|c|}
\hline Empresa & 1985 & 1987 & 1993 & 1994 & 1995 & 1998 & 1999 \\
\hline Nova Próspera & $1.827,51$ & $1.126,92$ & $17.978,58$ & $28.104,95$ & & & \\
\hline Metropolitana & $1.903,47$ & $2.527,96$ & $28.790,86$ & $27.889,68$ & $29.377,30$ & $57.064,08$ & $64.222,05$ \\
\hline Criciúma & $1.169,08$ & 766,81 & $12.884,72$ & $15.408,81$ & $17.915,72$ & 85.57539 & $5.450,92$ \\
\hline Urussanga & $1.475,14$ & 1361,38 & $25.268,47$ & $24.831,62$ & $42.476,39$ & & \\
\hline Treviso & $1.732,41$ & 2235,86 & $27.629,72$ & $91.469,25$ & & & \\
\hline Cooperminas & 8,96 & 644,06 & $10.072,57$ & $7.320,52$ & & $25.629,52$ & $27.909,80$ \\
\hline Barro Branco & $1.169,15$ & 437,35 & $13.940,00$ & $25.015,18$ & 38352,00 & $74.895,06$ & $13.444,92$ \\
\hline Ibramil & $1.465,35$ & 210,04 & $19.192,56$ & $12.572,36$ & $15.162,75$ & & \\
\hline Catarinense & $1.802,23$ & $1.469,07$ & $26.030,72$ & 29286,79 & $18.715,46$ & $65.753,70$ & $43.137,16$ \\
\hline Coque Catarinense & $2.533,22$ & $2.121,83$ & $16.528,04$ & $19.003,04$ & & & $42.936,73$ \\
\hline Rio Deserto & $5.416,19$ & $4.182,97$ & $7.675,27$ & $16.304,22$ & & 60304,85 & $59.491,38$ \\
\hline Belluno & & & 2718,49 & $13.776,40$ & $12.938,60$ & & $48.968,61$ \\
\hline Palermo & $3.509,55$ & & & & & & \\
\hline Carb. Santa Luzia & & & & & & $271.657,76$ & \\
\hline Minageo & & & & & & & 21337,80 \\
\hline Pérola & & & $9.599,01$ & & & & \\
\hline Comin & & & & & & & $53.965,35$ \\
\hline São Domingos & & & & & & & $51.220,40$ \\
\hline Total & $1.434,38$ & $1.205,06$ & $18.136,07$ & 21222,37 & $17.680,57$ & $53.172,03$ & $42.614,52$ \\
\hline Total em dólar & $10.218,60$ & $9.342,34$ & $18.136,07$ & $24.967,49$ & 18.227 .39 & $43.943,83$ & $23.160,07$ \\
\hline
\end{tabular}

Fonte: Elaborado pelo autor, a partir de dados levantados durante a pesquisa.

Obs.: Para saber se houve um crescimento no faturamento por trabalhador no setor carbonífero tivemos que dolarizar todos os valores, uma vez que eles estão num período que sofreu três mudanças de moeda (cruzeiros, cruzados e real) e estavam expressos no Informativo Anual da Indústria Carbonífera em OTN para os anos de 1985 e 1987, em dólar para o ano de 1993 e para os demais em real. Assim, convertemos todos os valores para dólar, à exceção de 1993, já expresso naquela moeda, utilizando o dólar médio de dezembro de cada ano, para venda, publicado pelo Banco Central do Brasil.

Utilizamos como contagem à adoção de cinco pontos para aquela que ficou em primeiro lugar no ano, quatro para o segundo lugar e assim por diante, até o quinto lugar, com um ponto. Assim, como a Metropolitana ficou em primeiro lugar por dois anos (1993 e 1999), uma vez em segundo (1981), uma em terceiro (1995) e duas em quatro lugar (1985 e 1994).

Em segundo lugar ficou a Rio Deserto. O interessante é que ela ficou em primeiro lugar por duas vezes, na década de 1980, voltando 
a figurar entre as cinco primeiras só em 1998, alcançando o segundo lugar no ano seguinte, muito embora a CCU, outra carbonífera do grupo Empresas Rio Deserto, fechada em 1996, tenha obtido o primeiro lugar justamente no último ano de operação (1995) e um quarto lugar em 1993. Se fôssemos considerar os grupos empresarias e não as empresas, o Rio Deserto estaria em primeiro lugar, com 22 pontos. Em terceiro lugar está a Treviso. Ela conseguiu essa posição em faturamento/homem justamente nos anos entre o período de crise, ou seja, em 1987,1993 e 1994. Em quarto lugar, vem a Carbonífera Catarinense. Em quinto lugar a Barro Branco, e em sexto a Urussanga.

Todas as empresas até agora citadas, nos anos em que estavam acima da média do setor, o que significa dizer que sempre houve no mínimo cinco indústrias acima da média de faturamento por trabalhador/ano. Há seis indústrias carboníferas que só operaram um ano. Dessas, apenas a Pérola e a Minageo não obtiveram um faturamento/homem, acima da média do setor, portanto, estando entre as cinco que mais faturaram por trabalhador. As outras quatro obtiveram bons faturamentos/homem. Oportuno também registrar que, além dessas que só operaram um ano, a única que nunca figurou entre as cinco primeiras e que obteve sempre um faturamento acima da média foi a Cooperminas. É lamentável não possuirmos dados sobre faturamento das indústrias antes de 1987 (à exceção de 1985, quando a CBCA já estava em crise), para podermos saber se esse fato é fruto da política adotada pela Cooperminas ou é resultado do tipo de lavra e de mina da carbonífera. Após a operação constatamos que, com exceção de 1987 e 1995, os anos estudados foram de constante crescimento, com índice de 126,6\% para o período de 1985 a 1999.

O que deu para perceber é que o avanço da Política Neoliberal, com o fim dos subsídios já na década de 1980 e a desregulamentação da atividade e as privatizações na década de 1990, provocaram uma redução na oferta de vagas ao mercado de trabalho, com a queda significativa também dos salários.

As relações, entre capital e trabalho passaram a favorecer os mineradores, uma vez que o aumento do Exército Industrial de Reserva acabou pressionando os mineiros, que, embora com uma história de combatividade, entraram na "onda" de sindicalismo ou tempos neoliberais e passaram a lutar pela manutenção dos empregos, deixando as lutas históricas por melhores salários e melhores condições de trabalho. A única coisa que não diminuiu foi à exploração da 
classe trabalhadora, uma vez que o faturamento por trabalhador aumentou bastante de 1985 a 1998 .

\section{Referências}

ALVES, p. 109-111. In.TEIXEIR A, Francisco J.S.\& OLIVEIR A, Manfredo Araújode. (org.) et. al. Neoliberalismo e Reestruturação Produtiva: as novas determinações do mundo do trabalho. 2a ed. São Paulo: Cortez, Fortaleza: Universidade Estadual do Ceará, 1998: ALVIM. A Trama da Privatização: A Reestruturação Neoliberal do Estado. Florianópolis: Insular, 2001:13-27.

ANTUNES, Ricardo. Neoliberalismo, trabalho e sindicatos: Reestruturação produtiva na Inglaterra e no Brasil. $2^{a}$ ed., 1998.

ANT UNES, Ricardo.Adeus ao Trabalho?: ensaios sobre as metamorfoses e a centralidade do mundo do trabalho. 7 a ed. ver. ampl. São Paulo: Cortez; Campinas, SP: Editora da Universidade Estadual de Campinas, 2000.

ANTUNES, Ricardo. Os Sentidos do Trabalho: ensaios sobre a afirmação e a negação do trabalho - 6 reimpressão. - São Paulo: Boitempo, SP, 2003.

B O X B ER GER, Gerald. \& K LIMENT A, Harald. As Dez Mentiras Sobre a Globalização. São Paulo: Aquariana, 1999.

CARNEIRO, Ricardo, Desenvolvimento em crise: a economia brasileira no último quarto do século XX - São Paulo: Editora UNES P - Unicamp, 2002.

Centro Itata - Centro Interdisciplinario de Estudios y Desarrollo Regional. El Desarrollo Regional desde el Mundo Social. Concepcion, Editora Anibal Pinto, 1992:76.

CHOINACKI, Luci. Mineiros de Santa Catarina: sua luta e sua história. Brasília: Câmara dos Deputados, 1993

C U NHA, Idaulo J.A Indústria Catarinense Rumo ao Novo Milênio: desafios, evolução e oportunidades. Florianópolis, 1997.

Departamento Intersindical de Estatística e Estudos Sócio-Econômicos - DIEESE-SC. Anuário dos Trabalhadores: Santa Catarina. Florianópolis, DIEESE-SC, 1999.

DIEESE-SC. Anuário dos Trabalhadores: Santa Catarina. Florianópolis, DIEESE-SC, 1999.

FERREIRA, Alceu Conceição \& ALVIM, Valdir (org). A Trama da Privatização. Florianópolis: Insular, 2001.

GENTILI, P, S A DER, Emir, (Org.), Pós-Neoliberalismo:As políticas sociais e o estado democrático, Paz e Terra, 1995.

GOETHE, Carlos A. Diagnóstico Ambiental da Região Carbonífera Catarinense. In: Anais do $2{ }^{\circ}$ Encontro Nacional de Estudos Sobre o Meio Ambiente. Florianópolis. v. 1,29 set. 1989

GU GLIELMI, R. Carvão. Florianópolis: Estado de Santa Catarina, Casa Civil, Janeiro, 1980.

IANNI, Octavio. Estado e Planejamento Econômico no Brasil. 1971.6.ed. Rio de Janeiro: Civilização Brasileira, 1996. 
LINS, Hoyêdo Nunes. O Alvorecer de um Novo Século. In.: S A N T OS, Sílvio Coelho dos (org.) Santa Catarina no século X X: ensaios e memória fotográfica. Florianópolis: Ed.da U F S C / U N I V A L I / F C C Edições, 1999:215.

OURIQUES, Nildo Domingos \& RAMPINELLI, Waldir José, organizadores, No fio da Navalha: crítica das reformas neoliberais de FHC. 2.ed. São Paulo, Xamã 1997.

Plano Básico de Desenvolvimento Ecológico - Econômico. A M R E C U N E S C, v.l, 1997.

SANTOS, Maurício Aurélio dos. Os sistemas de transportes em Santa Catarina: uma contribuição ao ensino de geografia. In.: Revista Episteme.Tubarão:, v.1, n.2/4, mar/fev 1994-1995, p. $115 / 137$.

S ANTOS, Maurício Aurélio dos. Crescimento e Crise na Região Sul de Santa Catarina. Florianópolis: U DES C, 1997.

S ANTOS, Maurício Aurélio dos. Acumulação, geração de emprego e diversificação da economia no Sul de Santa Catarina: carvão, cerâmica e a indústria de plásticos. Tese de doutoramento apresentado a FFLCH da USP, maio de 2002.

SILVA JR., José da. Santos Guglielmi: A Trajetória do Empreendedor. Criciúma. Florianópolis: Empresa Guglielmi, 1998.

SINGER, Paul. Globalização e Desemprego: Diagnóstico e Alternativas. 3 ed. São Paulo, Contexto. 1999.

TEIXEIRA, Francisco J.S . (org.) et. al. Neoliberalismo e Reestruturação Produtiva: as novas determinações do mundo do trabalho. 2a ed. São Paulo: Cortez, Fortaleza: Universidade Estadual do Ceará, 1998.

VOLPATO, Terezinha Gascho.A Pirita Humana: os Mineiros de Criciúma. Florianópolis, UFS C, 1984.

VOLPATO, Terezinha Gascho. Os Trabalhadores do Carvão: A Vida e as Lutas dos Mineiros de Criciúma. (Tese de Doutorado) USP, 1989.

ZAPATA, Francisco. Crise do sindicalismo na América Latina. Dados - Revista de Ciências Sociais, v. 37, n. 1, Rio de Janeiro, IUPERJ, 1994.

Revista Isto É. ${ }^{\circ} 1516,21 / 10 / 1998: 32$

Revista Isto É. $n^{\circ} 1677,21 / 11 / 2001: 81$

Jornal Diário Catarinense. R B S . Florianópolis: 2 8/08/94: 03

Jornal da Manhã.Tubarão: 03/04/1996:5. 